\title{
Validating the map of current semi-natural ecosystem types in Germany and their upscaling using the Kellerwald-Edersee National Park as an example
}

\author{
Stefan Nickel ${ }^{1 *}$ (ID, Winfried Schröder ${ }^{1}$ and Barbara Völksen ${ }^{2}$
}

\begin{abstract}
Background: Implementation Action 5 of the EU Biodiversity Strategy to 2020 includes that Member States map and assess the state of ecosystems and their services in their national territory. A fundamental component of the respective methodology developed in Germany is the classification of semi-natural ecosystems. In this context, this study aims to examine the quality and re-usability of the map of current semi-natural ecosystem types (cEsT) in Germany (1: 500,000; Jenssen et al. in Forschungsvorhaben 371083 214, UBA-FB 001834. UBA-Texte 87/2013. Dessau, Textband + 9 Anhänge, 381 S, 2013; Schröder et al. in Sci Total Environ 521-522:108-122, 2015, in Abschlussbericht Forschungsvorhaben UFOPLAN 371383254 im Umweltforschungsplan des Bundesministeriums für Umwelt, Naturschutz, Bau und Reaktorsicherheit, Bd. 1:1-493 + 7 Anhänge, Bd. 2:1-343, Bd. 3:1-303. Dessau, 2018]) as well as the cEsT map of the Kellerwald National Park (1: 25,000).
\end{abstract}

Results: Based on DIN EN ISO 19113 and (DDGI in Qualitätsmodell für die Beschreibung von Geodaten (PAS 1071:2007-10), Beuth Verlag, Berlin, 14 S. + Anh, 2007), the positional accuracy (absolute positional accuracy) and thematic accuracy (classification correctness) were quantitatively determined. For this purpose, a comparison was made with geometrical data of well-known positional accuracy such as ATKIS-DLM (Hesse), mapping of biotopes and habitat types (Hesse, Germany), current vegetation surveys from the Kellerwald National Park (Hesse; permanent random sample inspection, own survey) as well as vegetation surveys available Germany-wide after 1990 from the database of the Institute of Forestry Eberswalde (Waldkunde-Institut Eberswalde; W.I.E.). The map of cEsT Germany has an absolute positional accuracy of $\pm 42.29 \mathrm{~m}(\approx \pm 42 \mathrm{~m})$ and has been classified correctly by about $30 \%$. Another approximately $35 \%$ are ecologically similar to the existing forest ecosystem types (together 65\%). In a further approximately 15\%, the ecosystem types were correctly classified, but only occur as accompanying ecosystem types. About 15\% occurred as an ecologically related accompanying ecosystem type (together 30\%). 5\% of the spatial objects were mapped incorrectly. In the Kellerwald National Park (1:25,000), about 22\% of the cEsT were classified correctly. Misclassifications on both scale levels concerned the assignments to the elevation levels (e.g., Eb-5n-C2 instead of D1-5n-C2) and, respectively, to the humus species (e.g., Eb-5n-D1 instead of Eb-5n-D1a). The main reason for misclassifications can be seen in high thematic differentiation of the ecosystem classification according to Jenssen et al. (2013). The biotope and habitat mappings are, due to their generally lower thematic differentiation, more appropriate for a falsification than for a verification of the CEST approach. However, the spatial information content is valuable for comparisons with regard to the occurrence of cEsT as the main or concomitant ecosystem type.

\footnotetext{
*Correspondence: stefan.nickel@uni-vechta.de

${ }^{1}$ Chair of Landscape Ecology, University of Vechta, Postfach 1553, 49364 Vechta, Germany
}

Full list of author information is available at the end of the article 
Conclusions: The correctness of the classification can best be verified by vegetation samplings, but only at the site level. Any deviations found could then be used to improve the quality of the CEsT mapping, particularly at the regional level $(1: 5000$ to 1:25,000). In principle, the use of the identification key for forest and forest ecosystem types (Schröder et al. 2018, vol. 3) is recommended for mapping on a regional scale.

Keywords: Ecosystem classification, GIS mapping, Quality control, Vegetation surveys

\section{Background}

Action 5 of the EU Biodiversity Strategy to 2020 foresees that Member States will map and assess the state of ecosystems and their services in their national territory. To this end, an operational guidance to the EU and the Member States on how to assess the condition (or the state) of Europe's ecosystems was developed [15]. Accordingly, ecosystem condition should be measured using indicators and specified for the national level of the EU member states [15]. For Germany, a spatially explicit and nationally applicable concept for the classification of changes in ecosystem integrity was developed [10, 12, $16,17,19,21]$. A fundamental component of the methodology is the classification of Germany's semi-natural ecosystems. Their concordance with other ecosystem classifications for which no spatial concretisation has been carried out nationwide (EUNIS, Rieken et al. [18]; habitat types according to Annex I of the Habitats Directive) has been achieved. Thus, the developed ecosystem classification is connectable, and the systematizations associated with it gain in ecologically founded interpretability and spatial differentiation. For 61 ecosystem types (40 semi-natural, 21 intensively managed), a historical reference condition was quantified based on data from the period 1961-1990 [10, 12, 19, 20]. The reference condition was quantitatively described as a type-specific condition of ecosystems, the characteristics of which are characterized by intervals of historical condition variables (1961-1990) that are less affected by substance inputs and climate change than those of subsequent periods.

For habitat function, net primary function, carbon storage, nutrient flow, water flow and adaptability of ecosystem types, indicators were selected with which current and modeled future ecosystem conditions can be compared with the respective ecosystem type-specific reference conditions. The indication was quantitative with data from monitoring programs and from the W.I.E. database, whereby the focus was on the effects of changes in the abiotic systemic bases of development.

The reference states quantified for 40 semi-natural forest ecosystem types and 21 intensively managed forests refer to the period up to 1990, mainly from 1960 onwards, but in individual cases to data dating back to the 1920s and 1930s. For each ecosystem type, its reference status is indicated by a data sheet with the following information:

1. Ecosystem code: 1st digit=climate ecological coordinate, 2nd digit=water balance type, 3rd digit $=$ substance cycle type, description see identification key [20, vol. 3],

2. Ecosystem name,

3. EUNIS class,

4. Biotope type BfN [18],

5. Vegetation type according to common plant sociological classifications,

6. Photo,

7. Habitat type according to the Fauna-Flora-Habitat Directive [22],

8. Position in two-dimensional ecograms with the coordinates soil moisture and base saturation,

9. Location factors: soil shape, soil type, terrain, macroclimate,

10. Habitat function: characteristic species association with continuity and mean quantity development of the soil cover, maximum Kullback distance of the individual records to the mean species quantity distribution, minimum similarity of the individual records with the mean species quantity distribution,

11. Net primary production: above-ground average annual NPP at the time of culmination in tree wood, leaf/needle mass, ground vegetation and total mass, upper stand height at age 100 as comparative parameter,

12. Carbon storage: carbon stock in humus $\left(\mathrm{C}_{\text {org }}\right.$ in humus layer and in soil up to $80 \mathrm{~cm}$ depth),

13. Nutrient flow: $\mathrm{pH}$ value in $1 / 10 \mathrm{KCl}$, base saturation $V$ in \% and $C / N$ ratio in the uppermost $5 \mathrm{~cm}$ from $\mathrm{H}$ to Ah horizon (interval of mean value and standard deviation), humus form, nutritional characteristics $\mathrm{N} \%, \mathrm{P} \%, \mathrm{~K} \%, \mathrm{Ca} \%, \mathrm{Mg} \%$ in the assimilation apparatus of trees in $\mathrm{g} / 100 \mathrm{~g}$ of leaf/needle dry matter (August, interval of mean value and standard deviation),

14. Water flow: soil moisture index (interval from mean value and standard deviation) as well as. 


\section{National scale}

\section{Regional scale}

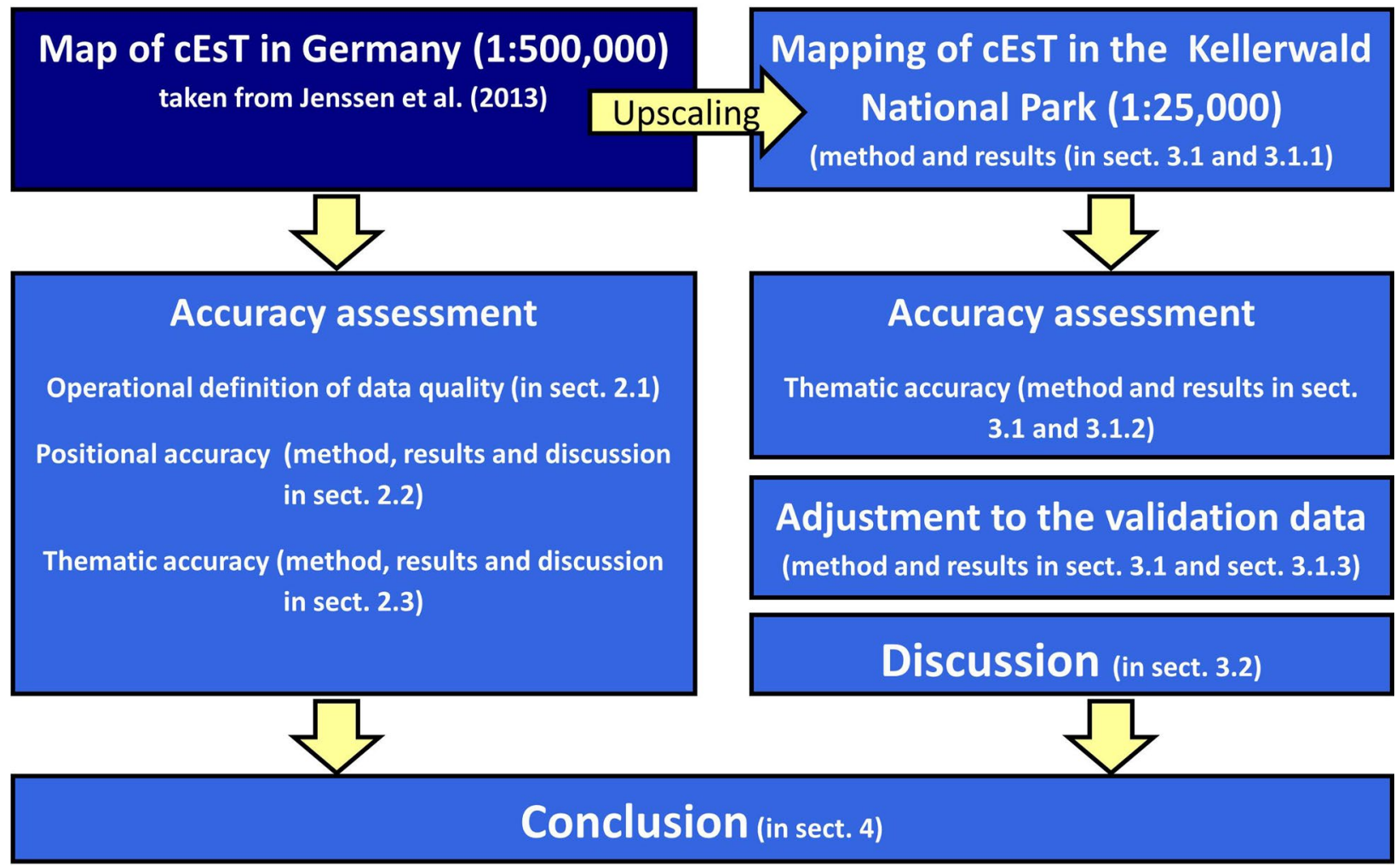

Fig. 1 Article structure. cEsT current semi-natural ecosystem types

15. Adaptation to changing environmental conditions: maximum proportions of natural site tree species in self-organized development stages.

The aim of the present study was first to test the quality of the map of Germany's current semi-natural ecosystem types (cEsT) on a scale of 1:500,000 [10,19] ("Methodology and results of the quality check" section). For observations of ecosystem integrity at the regional level (e.g., for nature conservation and forestry), the nationwide map of cEsT is only of limited use due to its small map scale-dependent spatial resolution and accuracy. Largescale or medium-scale mapping of ecosystem types with the help of vegetation surveys satisfy the accuracy requirements for the above-mentioned purposes at the local and, respectively, regional level, but are comparatively time-consuming and therefore impracticable. This methodological gap will, therefore, be closed in "Mapping of current semi-natural ecosystem types (cEsT) at regional scale and quality check" section by a procedure for medium-scale mapping of ecosystem types and assessment of the data quality for subsequent use after upscaling the nation-wide map using the example of the Kellerwald National Park, localized in the German federal state Hesse (Fig. 1).

\section{Methodology and results of the quality check Operational definition of data quality}

The quality was defined by the cartographic positional accuracy as well as the thematic accuracy, determined by a cartographic-statistical examination of the classification and its empirical validation with data not used for classification. Quality-related metadata have been determined which describe source-specific characteristics of data in terms of their quality. This is based on common standards for the description of the quality of geo-information: DIN EN ISO 19113 [8] and the quality model of the German Umbrella Association for Geoinformation e.V. based on it [4]. A quality model is understood to be a general and person-independent evaluation and description system for spatial data and their subsequent products. The DDGI quality model distinguishes between quantitative and non-quantitative quality information. Non-quantitative metadata refer in particular to the contents of the 
Table 1 Quality characteristics (according to DIN EN ISO 19113, [4]) and methods used

\begin{tabular}{lll}
\hline Quality features & Subcriteria (sub-elements) & Method \\
\hline Positional accuracy & Absolute (external) accuracy & Measurement of distances to ATKIS borders (Hesse) including error propagation \\
Thematic accuracy & Classification correctness & $\begin{array}{l}\text { 1. Comparison with empirical area-differentiated mapping data of the federal state } \\
\text { He-100\% } \\
\text { 0-100\% }\end{array}$ \\
& $\begin{array}{l}\text { 2. Comparison with ecosystem types derived from "point" vegetation surveys } \\
\text { (W.I.E.) }\end{array}$ \\
\hline
\end{tabular}

Table 2 Quantitative quality characteristics of the map of cEsT Germany 1:500,000

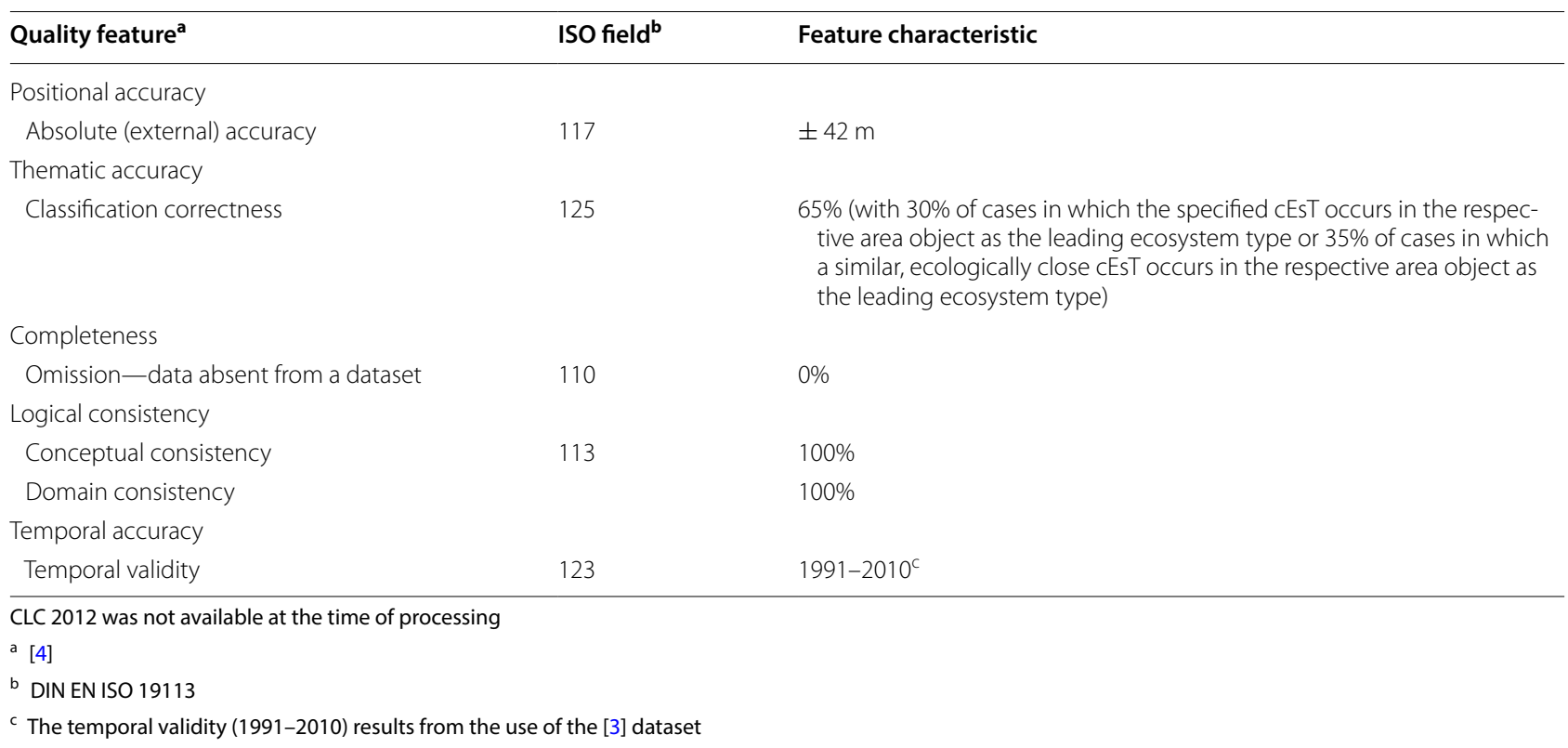

data set, the manufacturer and the original use, to origin and data sources as well as product characteristics (scale, product topicality, data type, etc.). Quantitative quality characteristics and the sub-elements assigned to them can characterize a geo-data set by measurable units. These quality characteristics can refer to different levels of a dataset, i.e., to the dataset as a whole (class), to a subset or to individual parts of the dataset, such as subtypes, objects or attributes [4].

The quality control of the cEsT data set was based on the following quality characteristics [4]:

1. Thematic accuracy (sub-element: classification correctness, i.e., accuracy of classification of objects and their relationships), and

2. Positional accuracy (sub-element: absolute (external) accuracy as a measure of the correspondence between the result of position determination and the true or accepted value of the position of an object).

Table 1 gives an overview of the methods used to determine these quality characteristics.
In the following, the methods and results including possible causes for identified deficiencies (geometry, topic) are explained. The results of the quality control of the map of Germany's current semi-natural terrestrial ecosystems (cEsT, 1:500,000) are summarized in Table 2 based on the standards of the DDGI Quality Model [4].

\section{Positional accuracy Method}

The estimation of the absolute positional accuracy of the cEsT surface geometries, i.e., their proximity to the true position value, was made by comparison with data of known positional accuracy. The Digital Basic Landscape Model (Basic DLM) of the Official Topographic Cartographic Information System Hessen (ATKIS Hessen) with a geometric accuracy of $\pm 3 \mathrm{~m}$ [7] was used as the reference data set. All deciduous, mixed and coniferous forests of the ATKIS-DLM were combined into a land use class "forest" and spatially overlaid with the land objects of the cEsT (forest and forest ecosystem types). Between 400 apparently identical entities in total, the distances between the respective representatives were measured 

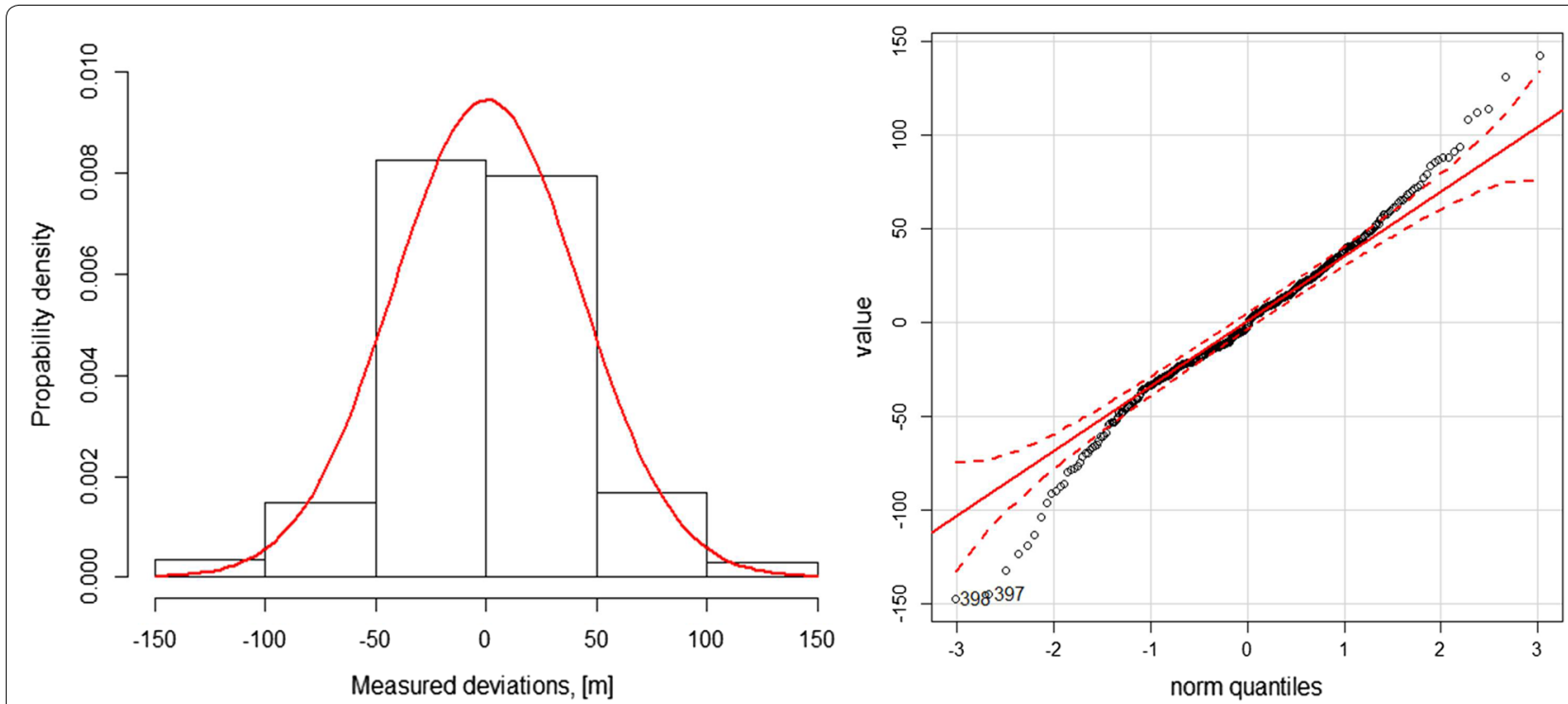

Fig. 2 Histogram and QQ plot of the measured deviations between ATKIS-DLM and CEsT geometries $(n=395)$

at selected support points of the object boundaries. For this, 200 cases were selected where the point objects of the reference data set (ATKIS) lie within the cEsT surfaces or 200 cases where these lie outside. Cases greater than three times the standard deviation were eliminated as outliers. The distribution properties were graphically displayed as histograms and quantile/quantile plots (QQ plots) and checked for normal distribution using the Shapiro-Wilk test. Based on this, the relative positional accuracy was first determined as the standard deviation of the measured values (Eq. 1).

$$
\sigma=\sqrt{\frac{1}{n-1} a^{2}+b^{2}+c^{2}+x_{n}^{2}}
$$

with: $\sigma=$ standard deviation; $n=$ sample size; $a, b, c \ldots$ $x=$ measured deviations.

In a second step, the absolute positional accuracy was determined in accordance with the general error propagation law (Eq. 2), taking into account the known positional accuracy of the reference data set.

$$
S=\sqrt{\sigma_{1}^{2}+\sigma^{2}}
$$

with: $S=$ absolute positional accuracy; $\sigma_{1}=$ standard deviation of the reference dataset (ATKIS).

\section{Results}

After elimination of outliers, the sample size amounts to $n=395$. The Shapiro-Wilk test shows no signs of normal distribution at a significance level of $\alpha=0.05$. Figure 2 shows at least a good approximation to the normal distribution.
The standard deviation of the distance measurements is calculated to $\pm 42.19 \mathrm{~m}$ (= relative positional accuracy of the cEsT geometries in relation to ATKIS). If the known positional inaccuracy of the ATKIS geometries according to Eq. (2) is added, the absolute positional accuracy of the cEsT is $\pm 42.29 \mathrm{~m}(\approx \pm 42 \mathrm{~m})$.

\section{Discussion}

The positioning inaccuracies are due to the scale inaccuracies of the input data, namely the map of potential natural vegetation PNV [2] and the land use units derived from the Corine Landcover 2006 [3]. The information on positional accuracy only refers to the accuracy of the forest/non-forest boundary.

\section{Thematic accuracy}

\section{Method}

The accuracy of the classification for the map of current semi-natural ecosystem types in Germany (cEsT, scale 1:500,000) was determined by Table 1 :

1. Comparison with empirical area-related mapping data of the Federal State of Hesse and

2. Comparison with ecosystem types derived from the W.I.E. database on the basis of vegetation surveys.

Validation with area-related vegetation data from Hesse The verification with empirical mapping data was based on the one hand on basic data surveys carried out in the German federal state Hesse in the NATURA 2000 areas no. 5517-301 Wehrholz (status 2012), no. 
5419-303 Wälder und Flachwasserteiche östlich Lich (status 2006), no. 4926-350 Boyneburg und Schickeberg bei Breitau (status 2004), no. 5917-305 Schwanheimer Wald (status 2004) as well as data from the large-scale nature conservation project Vogelsberg (status 2012). The evaluation of the accuracy of the classification was based on the assignments of cEsT (here: forest ecosystem types) to the types of potential natural vegetation (PNV) documented in Table 5, the biotope types according to the Hessian Biotope Mapping (HB) and the habitat types according to Annex I of the Habitats Directive. With regard to the types of forest ecosystems, data from the forestry institution (Hessen-Forst, FENA) and, in particular, data on the main tree species were also used. Since the ecosystem classification $[10,20]$ is generally more thematically resolved than the empirical mapping data, existing knowledge of the conditions in the above-mentioned areas was also used. The verification is based on a sample of 20 cEsT surface objects. This sample size corresponds to the required minimum number of samples (MPZ), which was determined on the basis of Eq. (3), which can also be applied to qualitative data [5]:

$$
\mathrm{MPZ}=10 * K^{V}
$$

with: $K=$ number of characteristic values, $V=$ number of characteristics considered.

Since in the case of the cEsT mapping only one single characteristic "Boolean value" $(V=1)$ is considered, where the number of characteristic values $K=2$ ("correct", "wrong"), an MPZ of 20 cEsT map objects results according to Eq. (4). In each case it was examined whether the ecosystem type specified for the respective cEsT site object occurs as a leading or accompanying ecosystem type or is not present at all. This is of importance, as strong inhomogeneities can occur within the cEsT map units due to the small map scale and the associated generalization of the cEsT map $(1: 500,000)$. The leading ecosystem type should be understood here as the predominant unit and the accompanying ecosystem type as an existing unit that cannot be represented due to its small-scale distribution.

Validation with vegetation data from the Institute of Forestry Eberswalde (W.I.E.) The determination of ecosystem types is ideally carried out with the greatest certainty according to the determination key for mapping on site [20, vol. 3]. If such a determination is not possible, an allocation can also be made by computer-assisted comparison of a vegetation survey of the investigated area with the reference conditions documented by Schröder et al. [20, vol. 2: Annex M2] and Jenssen et al. [11]. This is done by a computer program or a spreadsheet which calculates the distance between the vegetation composition of the area and the mean quantitative development of the ecosystem types (possible reference states) identified by Schröder et al. [20, vol. 2: Annex M2]. To validate the cEst map, data from historical vegetation surveys (prior to 1990) were used to construct ecosystem-type reference vectors to determine the current ecosystem type at each vegetation survey site studied after 1990, which was then used for comparison with the respective cEsT object. The distance measure calculated to the historical data is the Kullback information according to Eq. (4) [9, 13, 20: Chapter 7].

$$
K\left(p_{1}, \ldots, p_{S}, p_{1}^{O}, \ldots, p_{S}^{O}\right)=\sum_{i=1}^{S} p_{i} \ln \left(\frac{p_{i}}{p_{i}^{O}}\right)
$$

The $p_{i}$ denote the percentage development in volume of the species occurring on the area (indicated with ${ }_{i}$ ), the $p_{i}^{O}$ denote the reference condition of the vegetation derived from the totality of the vegetation relevés available for the respective ecosystem type. The coverage values totalled for all types are normalized to 1 according to Eq. (5), i.e.,

$$
\sum_{i=1}^{S} p_{i}=1
$$

An assignment is made to the ecosystem type to which the smallest Kullback distance exists. The following algorithm is used:

1. Manual selection of possible ecosystem types (reference conditions), e.g., via main tree species, humus form, geographical assignment. The following steps are performed for each possible ecosystem reference type:

2. Transfer of data on the reference type from the vegetation total tables for Jenssen et al. [11; "Ökocode_ Vegetationsgesamttabelle.xls"]. Reduction of the spreadsheet to recordings before 1991 by filtering in line "Date" (number of recordings/columns $=k$ ).

3. Create a reference vector $\left(p_{1}^{O}, \ldots, p_{R}^{O}\right)$ containing the mean quantity of species $p_{i}$ for each type of vegetation uptake indexed with $i(I=1, \ldots, R)$. The mean quantity of species is defined as the sum of all coverage values of a species occurring in the table in $\%$, divided by the number $k$ of vegetation surveys in the table [6, p. 203]. The cover values " + " and " $r$ " are set to 0.1 and 0.01 , respectively. Cells that are not occupied are set to zero. The coverage values of a species over different layers are added up. The mean species set $p_{i}^{O}$ of a species can be obtained in a spreadsheet by calculating the sum of all columns for each row (species) and dividing it by the number of total columns. Each species occupies exactly 
one line. The reference vector $\left(p_{1}^{O}, \ldots, p_{R}^{O}\right)$ is in a new column.

4. Creating a state vector $\left(p_{1}, \ldots, p_{Z}\right)$ that contains the coverage value $p_{i}$ for each type of vegetation survey of the study area $(I=1, \ldots, Z)$ indexed with $i$, analogous to step 3 .

5. Reduction of the reference vector $\left(p_{1}^{O}, \ldots, p_{R}^{O}\right)$ and the state vector $\left(p_{1}, \ldots, p_{Z}\right)$ to the number $S$ of species occurring both in the reference table and in the vegetation survey of the study area. You get two new vectors $\left(p_{1}^{O}, \ldots, p_{S}^{O}\right)$ and $\left(p_{1}, \ldots, p^{S}\right)$.

6. Normalization of the reference vector $\left(p_{1}^{O}, \ldots, p_{S}^{O}\right)$ by dividing each of its components $p_{i}^{O}$ (mean species sets for each species) by the sum of the mean species sets over all species, i.e.

$$
p_{i}^{O}:=\frac{p_{i}^{O}}{\sum_{i=1}^{S} p_{i}^{O}}
$$

In a spreadsheet, you get the normalized reference vector in a new column by dividing each cell by the column sum.

7. Normalization of the state vector $\left(p_{1}, \ldots, p_{S}\right)$ analog to step 6.

The following applies after execution of steps 6 and 7 .

$$
\sum_{i=1}^{S} p_{i}=\sum_{i=1}^{S} p_{i}^{O}=1
$$

as a precondition for step 8 .

8. Calculation of the Kullback distance $K\left(p_{1}^{O}, \ldots, p_{S}^{O}\right.$, $\left.p_{1}, \ldots, p_{S}\right)$ between the reference distribution of the ecosystem type and the species distribution of the investigated area according to Eq. 4.

9. Repeat steps 2 to 8 for all ecosystem types selected in step 1.

10. The study area is assigned to the reference type to which its vegetation composition has the smallest Kullback distance.

Example ICP Forests Level II site1605 (Großer Eisenberg, ThuringiaGermany).

The ICP Level II site 1605 Großer Eisenberg is located in the ridges of the Thuringian Forest and has the geographical coordinates ( $\mathrm{R} 3626697 \mathrm{H}$ 5609904). In this region, the ecosystem type C3-6d-B2 (Raw humus spruce, fir and beech forests of the altimontane level) can be identified in the cEsT map. Due to the low spatial resolution of this map, the assignment is now specified with the help of the procedure described above. Further possible ecosystem types will be selected and compared with vegetation data from 1960. In the present example, the ecosystem type C4-6d-B1 (Raw humus spruce forests of the altimontane level) is to be considered as a possible reference condition in addition to the ecosystem type C3-6d-B2. In Table 3, the reference vector $\left(p_{1}^{O}, \ldots, p_{R}^{O}\right)$ for the ecosystem type C4-6d-B1 is calculated exemplarily in the form of a spreadsheet. For this purpose a total of 36 vegetation surveys were selected from Jenssen et al. [11; "C4-6d-B1_Vegetationsgesamttabelle.xls"], which date from the years between 1942 and 1963 (step 2). Table 3 contains coverage values for a total of $R=59$ plant species. The mean species set $p_{i}^{O}$ for each of these species was determined by calculating the sum of all columns for each row (species) and dividing it by the number of total columns (step 3 ). The reference vector $\left(p_{1}^{O}, \ldots, p_{R}^{O}\right)$ is in the last column of Table 3. Table 4 contains the status vector $\left(p_{1}, \ldots, p_{Z}\right)$ with the coverage values of the occurring plant species (step 4) under the area number "STO180" in the third column. The 1960 vegetation relevés of the area LII1605 are documented under the area designation STO 180 [11]; ("C4-6d-B1_Vegetationsgesamttabelle.xls"). Table 4 was reduced to the 18 species that occur both in the reference table and in the vegetation survey of the study area (step 5). The fourth and fifth columns contain the normalized reference vector and the normalized state vector, respectively (steps 6 and 7). The last column contains the individual summands of the Kullback distance, whose sum in the last row of the last column yields the Kullback distance of $K=0.31$ between the reference distribution of the ecosystem type C4-6d-B1 and the species distribution of the study area in 1960 (step 8). These calculations were also carried out for type C3-6d-B2 and other possible ecosystem types (step 9). The value $K=0.31$ turned out to be the smallest Kullback distance. Thus, the ICP LII site 1605 Großer Eisenberg was assigned to the reference type C4-6d-B1 in 1960 due to its vegetation composition.

A total of 364 vegetation surveys after 1990 with known assignment of the current ecosystem type to the cEsT objects could be spatially linked and examined for agreement or disagreement.

\section{Results}

In the sample of the 20 cEsT map objects, a total of seven different wood ecosystem types (subatlantic lowland beech forest, conifer tree free beech mountain forest and black alder forest ecosystems) and three forest ecosystem types are represented. The sample, thus, includes widespread forest ecosystem types, with beech forests in particular occupying a special position in Central Europe due to their wide climatic amplitude and high tolerance to site conditions.

The evaluation on the basis of the area-related mapping data with expert knowledge of the area resulted in an accuracy of $65 \%$ with regard to the accuracy of the 


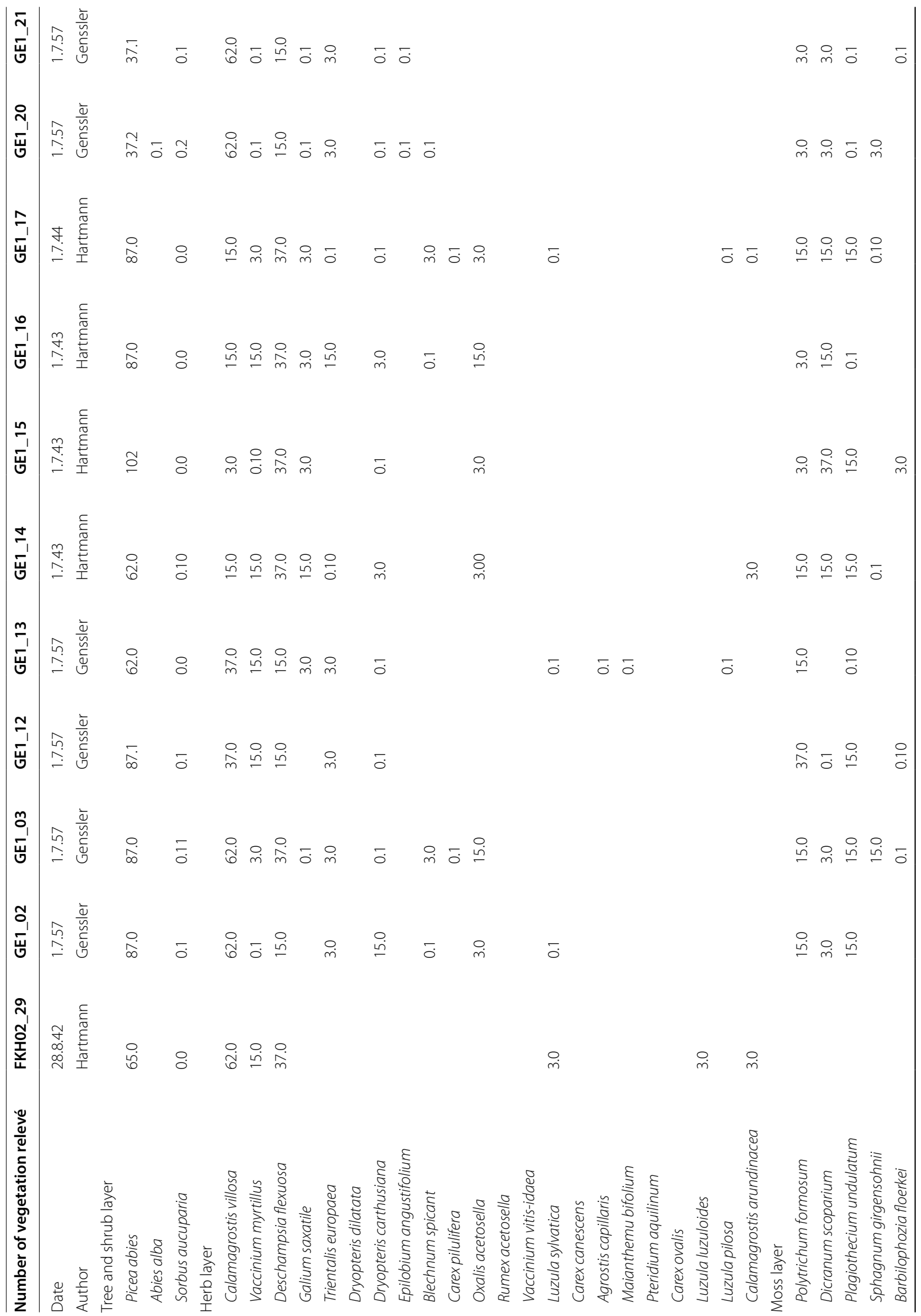


Nickel et al. Environ Sci Eur ～～(2019) 31:90

Page 9 of 20

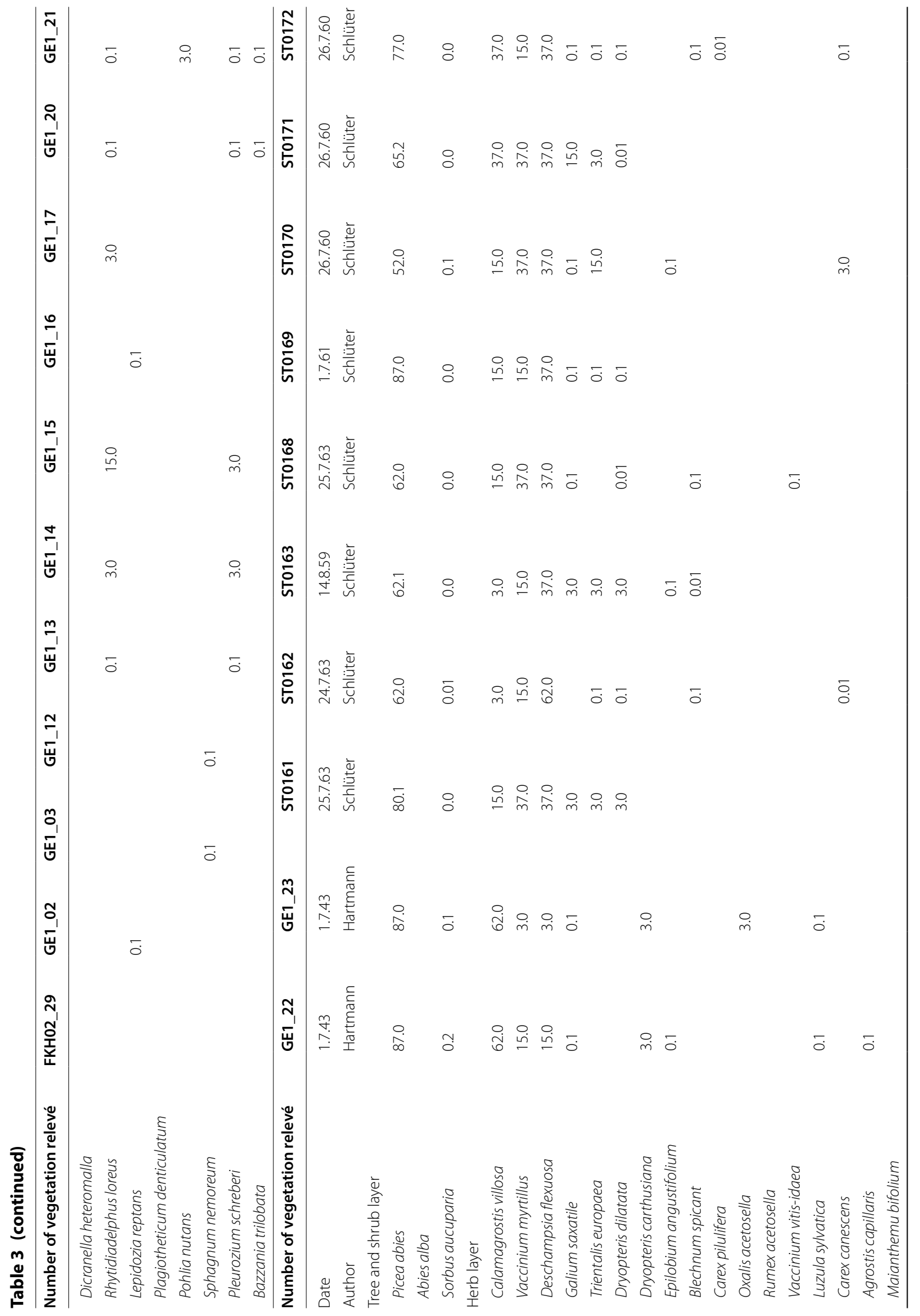




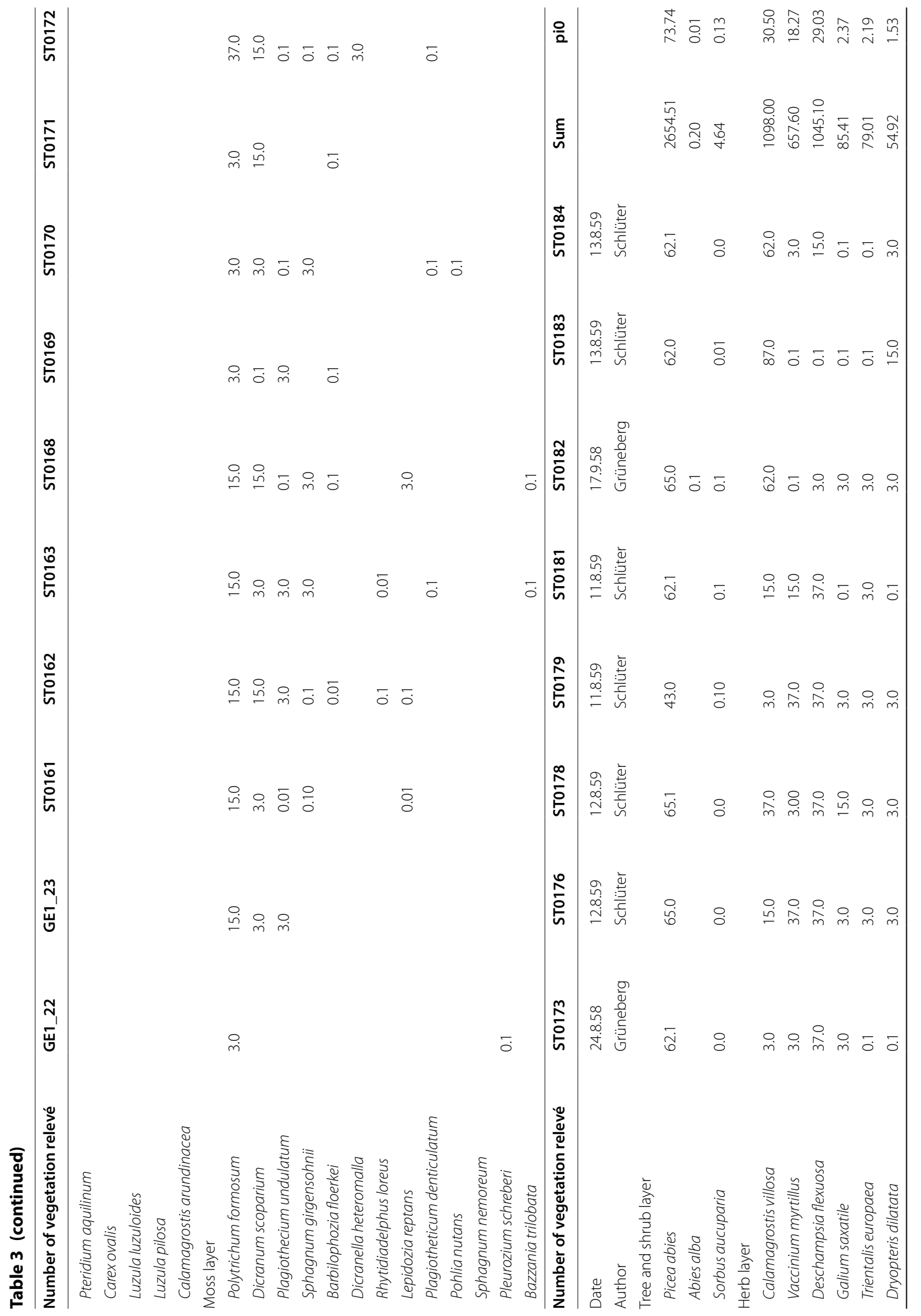




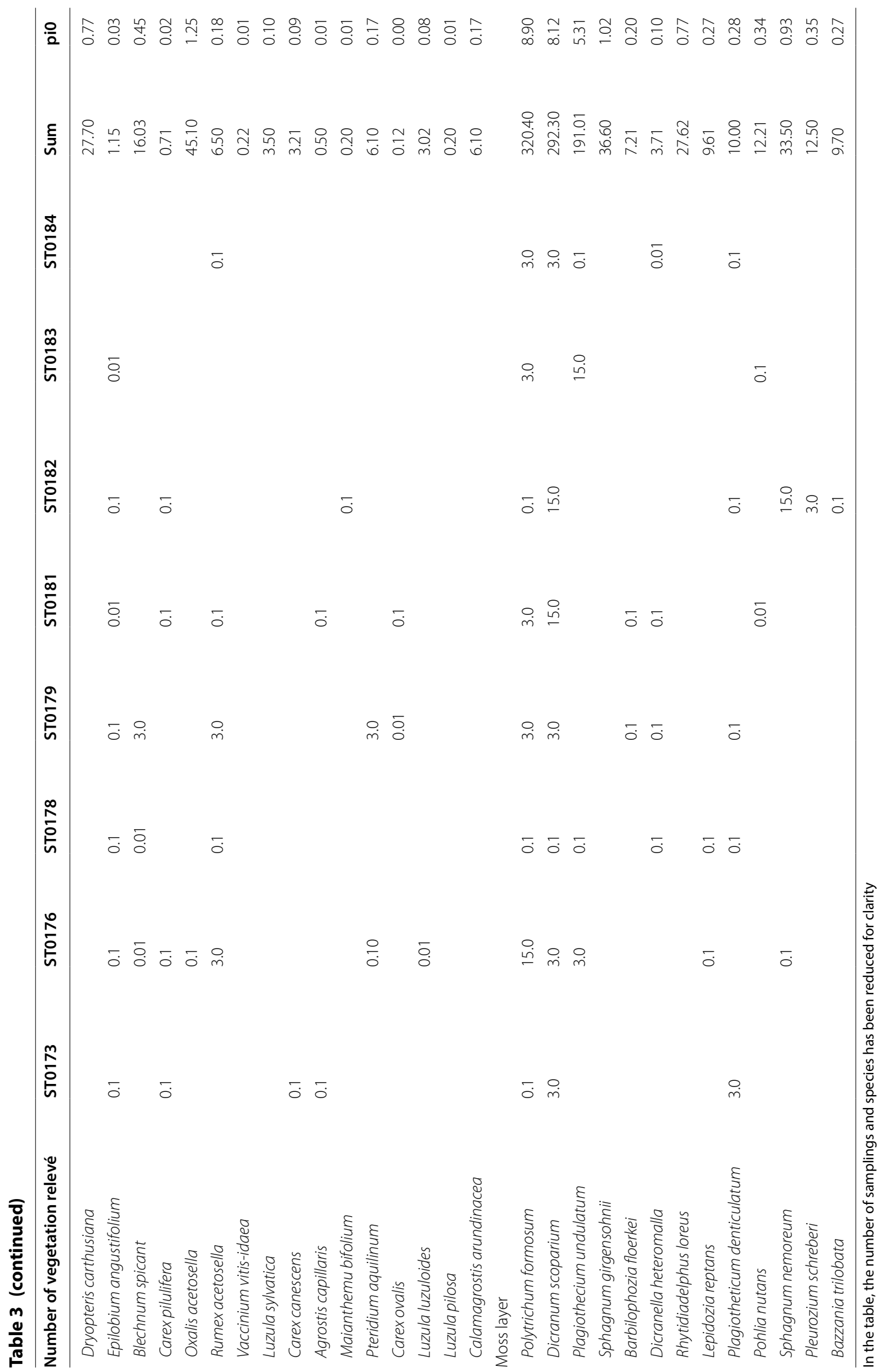


Table 4 Calculation of the Kullback distance between the ecosystem state vector $\left(p_{1}, \ldots, p_{Z}\right)$ of the sample site LII-1605 (Großer Eisenberg) and the reference vector $\left(p_{1}^{o}, \ldots, p_{R}^{o}\right)$ of the ecosystem type C4-6d-B1 (Table 3)

\begin{tabular}{|c|c|c|c|c|c|}
\hline Number of vegetation relevé & $p_{i}^{0}$ & ST0180 & $p_{i}^{0}$ normalized & $p_{i}$ standardized & $p_{i}^{*} \ln \left(p_{i} / p_{i}^{0}\right)$ \\
\hline Date & & 13.7 .60 & & & \\
\hline Author & & Schlüter & & & \\
\hline \multicolumn{6}{|l|}{ Tree and shrub layers } \\
\hline Picea abies & 73.7364 & 164.00 & 0.441779 & 0.543370 & 0.1125 \\
\hline Sorbus aucuparia & 0.0003 & 0.01 & 0.000002 & 0.000033 & 0.0001 \\
\hline Fagus sylvatica & 0.0003 & 0.10 & 0.000002 & 0.000331 & 0.0018 \\
\hline \multicolumn{6}{|l|}{ Herb layer } \\
\hline Calamagrostis villosa & 30.5000 & 15.00 & 0.182736 & 0.049698 & -0.0647 \\
\hline Vaccinium myrtillus & 18.2667 & 37.00 & 0.109442 & 0.122590 & 0.0139 \\
\hline Deschampsia flexuosa & 29.0306 & 37.00 & 0.173932 & 0.122590 & -0.0429 \\
\hline Galium saxatile & 2.3725 & 15.00 & 0.014214 & 0.049698 & 0.0622 \\
\hline Trientalis europaea & 2.1947 & 15.00 & 0.013149 & 0.049698 & 0.0661 \\
\hline Dryopteris dilatata & 1.5256 & 0.10 & 0.009140 & 0.000331 & -0.0011 \\
\hline Maianthemum bifolium & 0.0056 & 0.10 & 0.000033 & 0.000331 & 0.0008 \\
\hline Pteridium aquilinum & 0.1694 & 0.10 & 0.001015 & 0.000331 & -0.0004 \\
\hline Luzula pilosa & 0.0056 & 0.10 & 0.000033 & 0.000331 & 0.0008 \\
\hline \multicolumn{6}{|l|}{ Moss layer } \\
\hline Dicranum scoparium & 8.1194 & 0.10 & 0.048646 & 0.000331 & -0.0017 \\
\hline Barbilophozia floerkei & 0.2003 & 0.10 & 0.001200 & 0.000331 & -0.0004 \\
\hline Pleurozium schreberi & 0.3472 & 3.00 & 0.002080 & 0.009940 & 0.0155 \\
\hline Lophocolea heterophylla & 0.0139 & 0.10 & 0.000083 & 0.000331 & 0.0005 \\
\hline Dicranum majus & 0.4194 & 15.00 & 0.002513 & 0.049698 & 0.1483 \\
\hline Sum & 166.9078 & 301.82 & 1.000000 & 0.999967 & 0.3112 \\
\hline
\end{tabular}

classification, i.e., in about $2 / 3$ of the area objects, the cEsT indicated as the leading ecosystem type appeared plausible. In $30 \%$ of the cases, cEsT still appeared as an accompanying ecosystem type and in one case the indicated cEsT was not present on the investigated area. In the case of forest ecosystem types, the proportion of correctly classified objects according to this quality inspection method was 77\%; whereas in the case of forest ecosystem types, it was $43 \%$.

At the 364 vegetation survey areas with well-known cEsT, there is a correspondence with the map of cEsT Germany $(1: 500,000)$ in 104 cases $(=29 \%$ accuracy of the classification). If the three digits of the ecosystem key are separated, the result is $60 \%$ agreement for the eco-climatic classification, $44 \%$ agreement for the moisture index and $38 \%$ agreement for the material balance type. If only the forest ecosystem types are considered, the accuracy of the cEsT map is $39 \%$. For the eco-climatic classification, there is agreement at $67 \%$, for the moisture classification at $55 \%$ and for the material balance type at $44 \%$ of the 255 cases examined. Only $5 \%$ of the cEsT forest ecosystem types were correctly mapped. However, there are significantly higher similarities in the climate values (45\%), in the moisture index (18\%) and also in the material balance type (23\%).

\section{Discussion}

Methodical uncertainties in the determination of the characteristic values arise due to the small sample sizes ( $n=20 \mathrm{cEsT}$ area objects) as well as with regard to the classification as leading or accompanying ecosystem type. The latter is due in particular to a lack of data, i.e., insufficient coverage of the cEsT objects with corresponding empirical mapping data (7 out of 20 of the cEsT area objects investigated). When comparing with empirical mapping data, the greatest uncertainty results from the high differentiation of ecosystem classification $[10,20]$, since the mapping data are thematically less resolved. Even the use of field knowledge could not close this gap, since at the time of the field work, the mapping key for the ecosystem types [20, vol. 3] was not yet available. Validation on the basis of vegetation surveys is to be regarded as more reliable and leads to more divergent results. This is essentially due to the fact that on the basis of the available data, it was difficult to distinguish between ecologically related ecosystem types 
without further information. However, the site-specific consideration does not permit validation with regard to the occurrence as the main ecosystem type. In addition, the example of the fractured willow-black alder floodplain forests that accompany rivers and streams made it clear that the absolute positional (in)accuracy of the cEsT, which is $\pm 42 \mathrm{~m}$, generally makes it difficult to validate the linear objects in particular. The comparatively low hit rate for forest ecosystem types compared to forest ecosystem types can be attributed in particular to inaccuracies in the data bases used for cEsT mapping (Corine Landcover, tree species distribution). Problems with the interpretation of the cEsT map arise in particular also from the specification of only one cEsT for each spatial unit, whereby a spatial homogeneity is usually not present. This could be remedied by descriptive data that reflect the range of important characteristics or typical associations of different ecosystem types, as it is common in soil mapping [1], for example.

Overall, taking into account the results of both method applications, the following assessments can be made: In the map of cEsT Germany, the given main ecosystem type is correct to similar in $65 \%$ of cases, i.e., ecologically close (30\% correct; $35 \%$ similar). For $30 \%$ of the land objects, the cEsT specified is to be classified as the correct or ecologically related accompanying ecosystem type (about $15 \%$ correct and $15 \%$ similar). $5 \%$ of the area objects are mapped wrong.

\section{Mapping of current semi-natural ecosystem types (cEsT) at regional scale and quality check Method and results}

The methodology was developed and tested using the example of the Kellerwald-Edersee National Park (Hesse, federal state of Germany) in cooperation with the national park administration as a cooperation partner. The following data was used for this purpose:

1. Map of Current Near-Natural Ecosystem Types (cEsT) in Germany $(1: 500,000)$ [10, 20],

2. Basic data collection for the NATURA 2000 area No. 4920-401 Kellerwald with area-related data on the distribution of habitat types according to Annex I of the Habitats Directive and biotope types according to the Hessian Biotope Mapping Key (HB), ${ }^{1}$

3. Area-related data of the Hessian forest management $(\mathrm{FE})^{2}$ with information on the proportion of tree species and the age of the stand,

4. Site-related data on ecosystem types, determined on the basis of 105 vegetation surveys at 99 sites of the

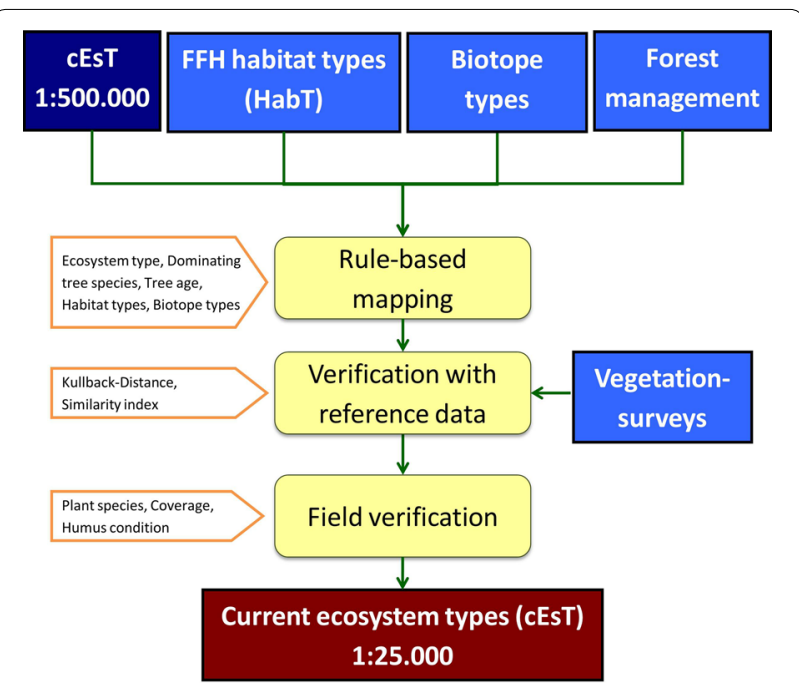

Fig. 3 Procedure of medium-scale mapping of the ecosystem types in the Kellerwald-Edersee National Park (Hesse, federal state of Germany)

Permanent Inventory of Forests (PSI) between 2007 and $2009^{3}$ and six own surveys in 2015 .

Figure 3 illustrates the principle of the methodological approach. In the first step, a rule-based mapping with available area-related data from the national park was carried out (variant $A$, simplified approach). The resulting map (scale 1:25,000) was then validated using site-specific data on woods and forest ecosystem types derived from vegetation surveys. In the third step, the results of the validation were used to improve the quality of the map (variant $B$ ). Finally, a comparison of both mapping approaches was made. At the same time, it was tested whether a random check in the field could replace the comparatively complex validation by means of vegetation surveys. This was done with the involvement of experts from the National Park Administration.

\section{Rule-based mapping}

Using the Kellerwald-Edersee National Park as an example, a hypothesis map of woods and forest ecosystem types (cEsT) was drawn up by applying area-specific defined classification rules to available information on the distribution of habitat types (HabT) according to Annex I of the Habitats Directive. Biotope types according to the key of the Hessian Biotope Mapping (HB), the regional hypsometric and horizontal eco-climatic classification

\footnotetext{
${ }^{3}$ Source: Northwest German Forest Research Institute Göttingen (NW-FVA).

\footnotetext{
${ }^{1}$ Source: Kellerwald-Edersee National Park Administration.

${ }^{2}$ Source: Landesbetrieb Hessen-Forst, Servicestelle Forsteinrichtung (FE).
} 
Table 5 Rules $^{\mathrm{a}}$ for deriving the hypothetical map of forest ecosystem types in the Kellerwald-Edersee National Park (Hesse, federal state of Germany) from available data

\begin{tabular}{|c|c|c|c|c|c|}
\hline \multicolumn{4}{|c|}{ Premise } & \multicolumn{2}{|c|}{ Conclusion } \\
\hline \multirow[t]{2}{*}{ HabT } & \multirow[t]{2}{*}{$\mathrm{HB}$} & \multirow[t]{2}{*}{ pEst } & \multirow[t]{2}{*}{ FE } & \multicolumn{2}{|l|}{ cEsT } \\
\hline & & & & Code & Name \\
\hline \multicolumn{6}{|c|}{ 1. Semi-natural forest ecosystem types } \\
\hline 9110 & & D1, Dg & & $D 1-6 d-C 2$ & Moder beech forests of the montane level \\
\hline 9110 & & D1, Dg & & Eb-5n-C2 & Moder beech forests on bunter \\
\hline 9130 & & D1, Dg & & $\begin{array}{l}\text { Eb-5n-D1 } \\
\text { Eb-5n-D1a }\end{array}$ & $\begin{array}{l}\text { Loamy mull beech forests } \\
\text { Sandy mull beech forests }\end{array}$ \\
\hline 9130 & & D1, Dg & & $\begin{array}{l}D 1-6 d-D 1 \\
D 1-6 d-E 1\end{array}$ & $\begin{array}{l}\text { Brown mull beech forests of the montane level } \\
\text { Mull beech forests of the montane level }\end{array}$ \\
\hline 9160 & 01.150 & & & $\begin{array}{l}\text { Eg-7 g-C1 } \\
\text { Eg-7 g-D1 }\end{array}$ & $\begin{array}{l}\text { Hygrophilous moder common oak and hornbeam forests } \\
\text { Hygrophilous brown mull common oak and hornbeam forests }\end{array}$ \\
\hline 9170 & 01.150 & & & Eg-2r-E2 & Thermophilous sessile oak forests on rocks \\
\hline $9180^{*}$ & 01.162 & & & Eg-5r-E1 & Whych elm and broad leaved lime forests on rocks \\
\hline \multirow[t]{2}{*}{$91 \mathrm{EO}^{*}$} & 01.173 & & & Dg-8z-D1 & Alluvial sycamore maple and black alder forests of the montane level \\
\hline & 01.142 & & & $\mathrm{Eg}-7 \mathrm{~g}-\mathrm{C} 1$ & Hygrophilous moder common oak and hornbeam forests \\
\hline \multicolumn{6}{|c|}{ 2. Intensively managed forest ecosystem types } \\
\hline & 01.183 & $\mathrm{~Eb}, \mathrm{Eg}$ & Oak & Eg-5n-c1 & Moder oak forests \\
\hline & 01.220 & $\mathrm{~Eb}, \mathrm{Eg}$ & & Eg-5n-c2 & Moder spruce forests \\
\hline & 01.220 & D1, Dg & & Dg-5n-c2 & Moder spruce forests of the montane level \\
\hline & 01.220 & $\mathrm{~Eb}, \mathrm{Eg}$ & Pine & $E b-4 n-c 2$ & Moder pine forests \\
\hline & 01.220 & D1, Dg & & Dg-5n-b1 & Raw humus spruce forests of the montane level \\
\hline & 01.300 & $\mathrm{~Eb}, \mathrm{Eg}$ & Oak & Eg-5n-c1 & Moder oak forests \\
\hline & 01.300 & $\mathrm{D} 1, \mathrm{Dg}$ & & $D g-5 n-c 2$ & Moder spruce forests of the montane level \\
\hline & 01.300 & $\mathrm{~Eb}, \mathrm{Eg}$ & & Eg-5n-c2 & Moder spruce forests \\
\hline & 01.300 & $\mathrm{~Eb}, \mathrm{Eg}$ & Pine & $E b-4 n-c 2$ & Moder pine forests \\
\hline & 01.300 & $\mathrm{~Eb}, \mathrm{Eg}$ & Larch & Eg-4n-b1 & Raw humus larch forests \\
\hline
\end{tabular}

HabT: Habitat types according to Annex I of the Habitats Directive: $9110=$ Luzulo-Fagetum (beech forests); $9130=$ Asperulo-Fagetum beech forests; $9160=$ SubAtlantic and medio-European oak or oak-hornbeam forests of the Carpinion betuli; $9170=$ Sub-continental oak-hornbeam forestst $($ Galio-Carpinetum); $9180 *$ TilioAcerion forests of slopes, screes and ravines; $91 \mathrm{E} 0^{*}=$ Alluvial forests with Alnus glutinosa and Fraxinus excelsior (Alno-Padion, Alnion incanae, Salicion albae) HB: Hessian biotope mapping: $01.150=$ oak forests; $01.162=$ other deciduous tree forests; $01.173=$ alluvial forests; $01.142=$ other oak-hornbeam forests; $01.183=$ other strongly cultivated wooded deciduous forests; $01.220=$ other coniferous forests; $01.300=$ mixed forests

pEsT: Regional hypsometric and horizontal eco-climatic classification of potential natural ecosystem types (pEsT, 1:500,000; [10, 20]): Eb = sub-atlantic, lowland; $\mathrm{Eg}=$ low to low mountain forest locations; $\mathrm{D} 1=$ mountain forest locations-conifer-free; $\mathrm{Dg}=$ mountain forest locations

FE: Information on main tree species (Hessian forestry management)

a If (premise), then (conclusion)

of the potential natural ecosystem types (pEst, 1:500,000 $[10,20])$ as well as data on the main tree species from the Hessian forest management (FE) in the premise part of the rule base (Table 5 ).

For example, the habitat type 9110 Luzulo-Fagetum (beech forests), mapped at a scale of 1:25,000 in the Kellerwald forest, was further differentiated into Moder beech forests of the montane level (D1-6d-C2) and Moder beech forests on bunter (Eb-5n-C2) by drawing on further information from the nationwide pEsT map for eco-climatic area classification $(\mathrm{D} 1=$ mountain forest location, $\mathrm{Eb}=\mathrm{low}$ to low mountain forest location). As another example,
21.67 ha of the Kellerwald National Park are occupied by the habitat type 91E0 'Alluvial forests' with Alnus glutinosa and Fraxinus excelsior (Alno-Padion, Alnion incanae, Salicion albae)' or biotope type 01.173 'Alluvial forests'. Both were assigned to the ecosystem type Dg-8z-D1 'Alluvial sycamore maple and black alder forests of the montane level', since the national map of cEsT also shows this ecosystem type in the Kellerwald National Park as the most frequent type of floodplain ecosystem. Figure 4 shows the hypothesis map developed in this way on a scale of 1 : 25,000 . 

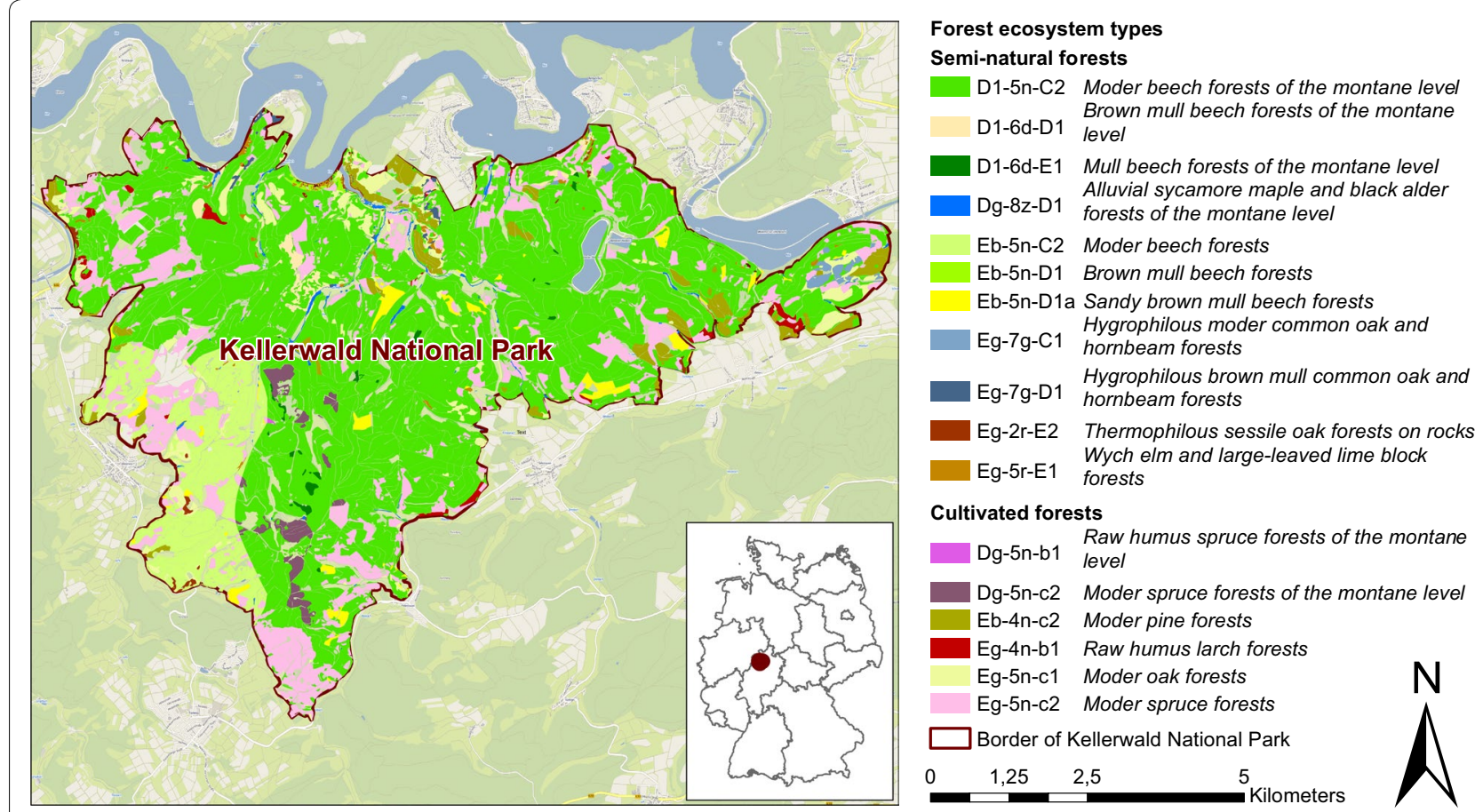

Fig. 4 Forest ecosystem types—Kellerwald-Edersee National Park (variant A), original scale 1:25,000

\section{Validation with vegetation data from the Kellerwald-Edersee National Park}

Due to the simplicity of the methodological approach, rule-based mapping (variant $A$ ) is associated with more or less large inaccuracies which can, however, be quantified. Accordingly, the thematic accuracy was determined on the basis of a random sample [20, vol. 1: Chapter 8.1] as a quality characteristic according to DDGI [4]. For this purpose, 82 vegetation surveys with known classifications of semi-natural forest and forest ecosystem types were available [20, vol. 1: Chapter 5].

Due to assumed geometric uncertainties, matches were tested in a 50-m buffer around the vegetation survey plots. As a result, at 18 of 82 vegetation sites $(=22 \%)$, the ecosystem types were correctly classified by rule-based mapping in the sense of all three site feature groups of the cEsT key. Frequent misclassifications concerned-as with the nationwide cEsT map-not only the assignment to the elevation level (e.g., Eb-5n-C2 instead of D1-5n-C2, Eb-5n-D1 instead of D1-6d-D1, Eg-5n-c2 instead of Dg$5 n-c 2)$, but also partial assignments to the substance balance type (e.g., Eb-5n-D1 instead of Eb-5n-D1a, Eg$7 \mathrm{~g}-\mathrm{C} 1$ instead of Eg-7g-D1). The misclassifications are, therefore, often similar to the results of rule-based mapping (variant $A$ ) and are ecologically related ecosystem types.

In addition, six cEsT sites were inspected by experts from the National Park Administration in June 2015. The following parameters (Table 6) were used for simplified relevés of these surface objects.

1. Number of vegetation layers in the forest and their respective coverage relative to the sample plot (in \%).

2. List of all higher plants and mosses occurring in the respective sample plot.

3. Coverage rate of the species in relation to the sample plot, e.g., according to Londo [14] [in \%].

This comparison yielded an estimated thematic accuracy of $80-90 \%$ for rule-based mapping.

\section{Adjustment to the validation data}

The misclassifications identified in the quality review were used to adapt the rule-based mapping to the validation data. This led in particular to area extensions in favor of the Moder beech forests of the montane level (D1-5n-C2), Sandy mull beech forests (Eb-5n-D1a), Brown mull beech forests of the montane level (D1-6d-D1) and Hygrophilous brown mull common oak and hornbeam forests (Eg-7g-D1) (Table 7). Ecosystem types with only one vegetation survey were not included in the quality improvement of the cEsT map.

\section{Discussion}

Without the mapping key [20, vol. 3], which was not yet available at that time, it was hardly possible for experts 
Table 6 Vegetation table for the quality control of rule-based mapping in the Kellerwald-Edersee National Park (Hesse, federal state of Germany)

\begin{tabular}{|c|c|c|c|c|c|c|c|c|c|}
\hline \multirow{2}{*}{$\begin{array}{l}\text { Parameter } \\
\text { Ecosystem group: }\end{array}$} & & & \multicolumn{5}{|c|}{ Semi-natural forest ecosystems } & \multirow{2}{*}{\multicolumn{2}{|c|}{$\begin{array}{l}\text { Intensively } \\
\text { managed forest } \\
\text { ecosystem types }\end{array}$}} \\
\hline & & & 1.1.1. & 1.6.2. & 1.3.1. & 1.3.1. & 1.5.1. & & \\
\hline \multirow{2}{*}{\multicolumn{3}{|c|}{ Forest ecosystem type: }} & Dg-8z-D1 & D1-6d-C2 & Eb-5n-D1 & Eb-5n-C2 & Eg-5r-E1 & $E b-4 n-c 2$ & \\
\hline & & & $\begin{array}{l}\text { Alluvial sycamore } \\
\text { maple and black } \\
\text { alder forests } \\
\text { of the montane level }\end{array}$ & $\begin{array}{l}\text { Moder beech } \\
\text { forests } \\
\text { of the montane } \\
\text { level }\end{array}$ & $\begin{array}{l}\text { Loamy } \\
\text { mull beech } \\
\text { forests }\end{array}$ & $\begin{array}{l}\text { Moder beech } \\
\text { forests } \\
\text { on bunter }\end{array}$ & $\begin{array}{l}\text { Whych elm } \\
\text { and broad leaved } \\
\text { lime forests on rocks }\end{array}$ & $\begin{array}{l}\text { Moder pine } \\
\text { forests *) }\end{array}$ & \\
\hline \multicolumn{3}{|l|}{ Habitat type: } & ${ }^{*} 91 \mathrm{EO}$ & 9110 & 9130 & 9110 & 9180 & - & \\
\hline \multicolumn{3}{|l|}{ Community } & Car. Rem.-Frax. & Luz.-Fag. & Asp.-Fag. & Luz.-Fag. & Tilio-Ac. & - & \\
\hline \multicolumn{3}{|l|}{ Plot No.: **) } & 1 & 2 & 3 & 4 & 5 & 6 & \\
\hline \multicolumn{3}{|l|}{ Survey date } & & & & & & & \\
\hline \multicolumn{2}{|c|}{ Stand height (m) (shrub layer) } & & $20-22$ & $30-35$ & 25 & 18 & 20 & $15-18$ & \\
\hline \multicolumn{3}{|l|}{ Coverage 1. Tree layer (\%) } & & 15 & 10 & 8 & 10 & $2-6$ & \\
\hline \multicolumn{3}{|l|}{ Coverage 2. Tree layer (\%) } & 4 & 2 & 1.5 & 2.6 & 4 & & \\
\hline \multicolumn{3}{|l|}{ Coverage shrub layer (\%) } & 60 & 60 & 25 & 40 & 40 & 29 & \\
\hline \multicolumn{3}{|l|}{ Coverage herb layer (\%) } & & 25 & 40 & 20 & 15 & 8 & \\
\hline \multicolumn{3}{|l|}{ Coverage moss layer (\%) } & 4.2 & 3.2 & 0.3 & 5.1 & 27 & & \\
\hline \multicolumn{10}{|l|}{$\mathrm{C} / \mathrm{N}$ weighted mean } \\
\hline \multicolumn{3}{|c|}{ Typical C/N ratio (ZNo. 3 eco-eode) } & & 0.1 & & 29 & & 25 & \\
\hline \multicolumn{3}{|c|}{$\begin{array}{l}\text { Humus form according to KA5, } \\
\text { Tab. } 56-58\end{array}$} & 13.18 & 17.74 & 15.62 & 23.09 & 14.81 & 29.42 & \\
\hline \multicolumn{3}{|c|}{ Stand height $(\mathrm{m})$ (shrub layer) } & & $13-18$ & 13-18 & $18-23$ & $11-14$ & & \\
\hline Species name & Layer & \multicolumn{8}{|c|}{ Dominance in \% } \\
\hline Acer platanoides & B1 & & & & & & 1 & & \\
\hline Acerpseudoplatanus & $\mathrm{B} 1$ & & & & & & 10 & & \\
\hline Alnus glutinosa & $\mathrm{B} 1$ & 40 & & & & & & & \\
\hline Betula pendula & B1 & & & & & & & & 1 \\
\hline Carpinus betulus & $\mathrm{B} 1$ & 15 & & & 5 & & & & \\
\hline Fagus sylvatica & B1 & & 60 & & 20 & 40 & & & \\
\hline Larix decidua & $\mathrm{B} 1$ & & & & & & & & 3 \\
\hline Pinus sylvestris & $\mathrm{B} 1$ & & & & & & & & 25 \\
\hline Salix caprea & B1 & 5 & & & & & & & \\
\hline Tilia cordata & $\mathrm{B} 1$ & & & & & & 25 & & \\
\hline Betula pendula & B2 & & & & & & & & 1 \\
\hline Carpinus betulus & B2 & & & & 10 & & 1 & & \\
\hline Fagus sylvatica & B2 & & 25.0 & & 30.0 & 20,0 & 1.0 & & 5.0 \\
\hline Pinus sylvestris & B2 & & & & & & & & 1.0 \\
\hline Quercus robur & B2 & & & & & & 3.0 & & 1.0 \\
\hline Tilia cordata & B2 & & & & & & 10.0 & & \\
\hline Ulmus glabra & B2 & & & & & & 3.0 & & \\
\hline Species name & Layer & Domin & cee in \% & & & & & & \\
\hline Acer platanoides & S & & & & & & 1.0 & & \\
\hline Acerpseudoplatanus & S & & & & 0.1 & & 3.0 & & \\
\hline Corylus avellana & S & & & & & & 10.0 & & \\
\hline Fagus sylvatica & S & 0.2 & 3.0 & & 0.2 & 5.0 & & & \\
\hline Lonicera xylosteum & S & & & & & & 3.0 & & \\
\hline Quercus robur & S & & & & & 0.1 & & & \\
\hline Ribes alpinum & $S$ & & & & & & 5.0 & & \\
\hline
\end{tabular}


Table 6 (continued)

\begin{tabular}{|c|c|c|c|c|c|c|c|c|}
\hline Species name & Layer & Dor & & & & & & \\
\hline Rubus idaeus & S & & & & & & & 0.1 \\
\hline Sambucus nigra & $S$ & 1.0 & & & & & & \\
\hline Sambucus racemosa & $\mathrm{S}$ & & & & & & & 1.0 \\
\hline Sorbus aucuparia & S & & & 0.2 & & & & 1.0 \\
\hline Tilia cordata & S & & & & & & & \\
\hline Ulmus laevis & $S$ & & & & & & & 3.0 \\
\hline Species name & Layer & Dor & & & & & & \\
\hline Acer campestre & K & 0.2 & & & & & & \\
\hline Acer platanoides juv. & K & & & & 0.2 & & & \\
\hline $\begin{array}{l}\text { Acer pseudoplata- } \\
\text { nus K. }\end{array}$ & K & & 0.1 & & & & & \\
\hline $\begin{array}{l}\text { Acer pseudoplatanus } \\
\text { juv. }\end{array}$ & K & & & & 0.2 & & & \\
\hline $\begin{array}{l}\text { Aegopodium podag- } \\
\text { raria }\end{array}$ & K & 0.2 & & & & & & \\
\hline Ajuga reptans & K & 0.2 & & & & & & \\
\hline Alliaria petiolata & K & 0.1 & & & & & & \\
\hline Anemone nemorosa & K & 3.0 & 0.2 & & 0.2 & & & \\
\hline Arum maculatum & K & 0.2 & & & & & 1.0 & \\
\hline Athyrium filix-femina & K & 0.2 & & & & & & \\
\hline $\begin{array}{l}\text { Brachypodium sylvati- } \\
\text { cum }\end{array}$ & K & 0.2 & & & & & & \\
\hline Cardamineflexuosa & K & 0.1 & & & & & & \\
\hline Cardamine impatiens & K & & & & & & 1.0 & \\
\hline Carex pilulifera & K & & 0.2 & & & & & \\
\hline Carex remota & K & 3.0 & & & & & & \\
\hline Carex sylvatica & K & 0.2 & & & & & & \\
\hline $\begin{array}{l}\text { Chrysosplenium } \\
\text { alternifolium }\end{array}$ & K & 1.0 & & & & & & \\
\hline $\begin{array}{l}\text { Chrysosplenium } \\
\text { oppositifolium }\end{array}$ & K & 1.0 & & & & & & \\
\hline Circea alpina & K & 0.1 & & & & & & \\
\hline $\begin{array}{l}\text { Crataegus laevigata } \\
\text { juv. }\end{array}$ & K & 0.2 & & & & & & \\
\hline $\begin{array}{l}\text { Deschampsia cespi- } \\
\text { tosa }\end{array}$ & K & 3.0 & 0.1 & & & & & \\
\hline Dryopteris carthusiana & K & & & & & & 5.0 & \\
\hline Dryopteris dilatata & K & 1.0 & & & & & & \\
\hline Dryopteris filix-mas & K & & & & 1.0 & & 1.0 & \\
\hline Epilobium spec. & K & & & & & & 0.2 & \\
\hline Fagus sylvatica K. & K & & & & & & 0.1 & \\
\hline Fagus sylvatica juv. & K & 0.2 & 1.0 & & 0.2 & 1.0 & & 0.2 \\
\hline Festuca altissima & K & & & & 5.0 & & 1.0 & \\
\hline Festuca gigantea & K & & & & & 1.0 & & \\
\hline Galium aparine & K & 0.2 & & & & & 1.0 & \\
\hline Galium odoratum & K & & & & 1.0 & & 3 & \\
\hline Galium sylvaticum & K & & & & & & 1.0 & \\
\hline
\end{tabular}


Table 6 (continued)

\begin{tabular}{|c|c|c|c|c|c|c|c|}
\hline Species name & Layer & Dom & & & & & \\
\hline Glechoma hederacea & K & 0.2 & & & & & \\
\hline Hypericum hirsutum & K & & & & & 0.2 & \\
\hline Impatiens noli-tangere & K & 1.0 & & & & & \\
\hline Impatiens parviflora & K & & & & & 1.0 & \\
\hline Lamium galeobdolon & K & 3.0 & & & & & \\
\hline Larix decidua & K & & & & & & 0.2 \\
\hline Luzula luzuloides & K & & 0.2 & & 5.0 & & \\
\hline Mercurialis perennis & K & & & 1.0 & & 20.0 & \\
\hline Moehringia trinervia & K & & & & & 0.2 & \\
\hline Oxalis acetosella & K & 1.0 & 0.2 & 1.0 & & & \\
\hline Phyteuma nigrum & K & 0.1 & & & & & \\
\hline Pinus sylvestris juv. & K & & & & & & 0.1 \\
\hline Poanemoralis & K & 0.2 & & & & & \\
\hline Polypodium vulgare & K & & & & 0.2 & & \\
\hline Prunus avium juv. & K & & 0.1 & & & & \\
\hline Quercus robur juv. & K & & & & 0.1 & & 0.1 \\
\hline Ranunculus ficaria & K & 30.0 & & & & & \\
\hline Rosa cf. arvensis & K & & & & & 0.2 & \\
\hline Rumex sanguineus & K & 1.0 & & & & & \\
\hline Sambucus racemosa & K & 0.1 & & 0.2 & & & \\
\hline Scrophularia nodosa & K & & & 0.1 & & & \\
\hline Sorbus aucuparia & K & & & & & & \\
\hline Sorbus aucuparia juv. & K & & 0,2 & & & & \\
\hline Stachys sylvatica & K & 1.0 & & & & & \\
\hline Stellaria nemorum & K & 1.0 & & & & & \\
\hline Urtica dioica & K & 1.0 & & 0.2 & & 1.0 & \\
\hline Vaccinium myrtillus & K & & & & 3.0 & & \\
\hline Acer spec. K. & K & & & 1.0 & & & \\
\hline Deschampsia flexuosa & K & & & & 1.0 & & 0.2 \\
\hline $\begin{array}{l}\text { Dianthus gratianopo- } \\
\text { litanus }\end{array}$ & K & & & & & & 0.2 \\
\hline Fagus sylvatica K. & K & & 1.0 & 0,2 & 0.2 & & 0.2 \\
\hline Species name & Layer & Don & $\%$ & & & & \\
\hline Polytrichum commune & M & & & & 8.0 & & \\
\hline Polytrichum formosum & M & & 0.1 & & & & \\
\hline Rhytidiadelphus loreus & M & & & & 1.0 & & \\
\hline Cladonia spec. & M & & & & & & 10.0 \\
\hline
\end{tabular}

$\mathrm{B} 1=$ first tree layer $\mathrm{B} 2=$ second $\mathrm{S}=$ shrub layer $\mathrm{K}=$ herb layer; $\mathrm{M}=$ moss layer 
Table 7 Area calculation for the ecosystem types mapped in the Kellerwald-Edersee National Park (Hesse, federal state of Germany; 1991-2010)

\begin{tabular}{|c|c|c|c|c|c|}
\hline \multirow[t]{2}{*}{ Eco code } & \multirow[t]{2}{*}{ designation } & \multicolumn{2}{|l|}{ Variant $A$} & \multicolumn{2}{|l|}{ Variant $B$} \\
\hline & & Area size (ha) & $\begin{array}{l}\text { Area } \\
\text { proportion } \\
(\%)\end{array}$ & Area size (ha) & $\begin{array}{l}\text { Area } \\
\text { proportion } \\
\text { (\%) }\end{array}$ \\
\hline D1-6d-C2 & Moder beech forests of the montane level & 852.74 & 16.81 & 3165.70 & 62.39 \\
\hline D1-6d-E1 & Mull beech forests of the montane level & 15.31 & 0.30 & 15.31 & 0.30 \\
\hline D1-6d-D1 & Brown mull beech forests of the montane level & - & - & 42.61 & 0.84 \\
\hline Dg-5n-b1 & Raw humus spruce forests of the montane level & 0.76 & 0.01 & 0.76 & 0.01 \\
\hline Dg-5n-c2 & Moder spruce forests of the montane level & 61.82 & 1.22 & 61.82 & 1.22 \\
\hline$E b-4 n-c 2$ & Moder pine forests & 163.15 & 3.22 & 163.15 & 3.22 \\
\hline$E b-5 n-C 2$ & Moder beech forests on bunter & 2732.36 & 53.85 & 410.55 & 8.09 \\
\hline Eb-5n-D1 & Loamy mull beech forests & 118.44 & 2.33 & 5.55 & 0.11 \\
\hline Eb-5n-D1a & Sandy mull beech forests & - & - & 79.13 & 1.56 \\
\hline Eg-2r-E2 & Thermophilous sessile oak forests on rocks & 12.07 & 0.24 & 12.07 & 0.24 \\
\hline Eg-4n-b1 & Raw humus larch forests & 29.68 & 0.59 & 29.68 & 0.59 \\
\hline Eg-5n-c1 & Moder oak forests & 175.26 & 3.45 & 175.26 & 3.45 \\
\hline Eg-5n-c2 & Moder spruce forests & 682.87 & 13.46 & 682.87 & 13.46 \\
\hline Eg-5r-E1 & Whych elm and broad leaved lime forests on rocks & 17.30 & 0.34 & 17.30 & 0.34 \\
\hline $\mathrm{Eg}-7 \mathrm{~g}-\mathrm{C1}$ & Hygrophilous moder common oak and hornbeam forests & 33.20 & 0.65 & 21.76 & 0.43 \\
\hline Eg-7g-D1 & Hygrophilous brown mull common oak and hornbeam forests & - & - & 11.44 & 0.23 \\
\hline Dg-8z-D1 & Alluvial sycamore maple and black alder forests of the montane level & 21.67 & 0.43 & 21.67 & 0.43 \\
\hline Other & Open fields, waters, roads & 157.30 & 3.10 & 157.30 & 3.10 \\
\hline Sum & & 5073.94 & 100 & 5073.94 & 100 \\
\hline
\end{tabular}

Variant $A=$ Rule-based mapping; variant $B=$ Rule-based mapping after adaptation to validation data

in the field to carry out an assessment, since it was often difficult for even experienced experts to distinguish ecologically related ecosystem types on the basis of the information contained in the profiles of ecosystem types alone, i.e., without vegetation surveys and subsequent evaluation on the basis of the reference conditions. For example, it was not possible to differentiate reliably between beech forests in the lower mountain region (level E) and beech forests in the mountain region (level D). However, the potential of the rule-based methodology lies in an efficient mapping in comparison to traditional field mapping in a map scale range commonly used in practice (e.g., nature conservation, forestry) (1:5000 to $1: 25,000)$. However, mapping based on existing data must be supplemented by a sufficiently dense network of vegetation surveys or be based on the mapping key developed [20, vol. 3] to ensure a more realistic approach to ecosystem types. But also when determining the most probable ecosystem type from the vegetation surveys [20, vol. 1: Chapter 5], it should be noted that the determination of the Kullback distance requires a corresponding reference description. Thus, spatially very dense surveys does not always yield the correct ecosystem type, as was demonstrated by the example of a Sandy mull beech forests (Eb-5n-D1a, location PW1), which would be plant-sociologically related to the Winkelseggen-ErlenEschen-Wald (Carici remotae-Fraxinetum) and thus to the Alluvial sycamore maple and black alder forests of the montane level (Dg-8z-D1, without reference condition). A similar occurrence occurred in a Whych elm and broad leaved lime forests on rocks (Eg-5r-E1, location PW5), which for the same reason was erroneously assigned to the Mull beech forests of the montane level (D1-6d-E1).

\section{Conclusions}

Rule-based mapping provides an approximate result (hypothesis map), of which the thematic accuracy can be quantified by taking vegetation surveys and observing a required minimum number of samples (MPZ). Any deviations found at the site level could be used to improve the quality of the hypothesis map, particularly at the regional level (1:5000 to 1:25,000). The rule base for deriving cEsT in the Kellerwald is not applicable under different conditions, meaning that for each other investigation area, a specific rule base has to be defined adapted to available data. On this spatial scale, it is also recommended, to use additionally the key for identifying forest ecosystems in Germany [20, vol. 3]. 


\section{Abbreviations}

ATKIS: Official Topographical Cartographic Information System; BfN: German Federal agency for nature conservation; Ca: calcium; cEsT: current semi-natural ecosystem types; CLC: CORINE Land Cover; $C_{\text {org }}$ : organic carbon; DLM: Digital landscape model; EU: European Union; EUNIS: European Nature Information System; FE: Forsteinrichtung (Hessian forest management); GIS: Geographical Information System; HabT: habitat types; ICP: International Cooperative Program; K: potassium; Mg: magnesium; MPZ: minimum number of samples; $n$ : sample size; N: nitrogen; NPP: net primary production; P: phosphorus; pEst: potential natural ecosystem types; PNV: potential natural vegetation; PSI: Permanent Inventory of Forests; V: base saturation; W.I.E.: Waldkunde-Institut Eberswalde (Institute of Forestry Eberswalde).

\section{Acknowledgements}

We would like to thank the Federal Environment Agency (Dessau-Roßlau, Germany) for its financial support and technical advice.

\section{Authors' contributions}

WS headed the computations executed by SN and BV. All authors participated in writing the article. All authors read and approved the final manuscript.

\section{Funding}

Funding was provided by Umweltbundesamt (Grant No. FKZ 371383 254)

\section{Availability of data and materials}

The datasets generated and/or analyzed during the current study are not publicly available due to copyright but are available from the corresponding author on reasonable request.

\section{Ethics approval and consent to participate}

Not applicable.

\section{Consent for publication}

Not applicable.

\section{Competing interests}

The authors declare that they have no competing interests.

\section{Author details}

${ }^{1}$ Chair of Landscape Ecology, University of Vechta, Postfach 1553, 49364 Vechta, Germany. ${ }^{2}$ PlanWerk, Office for Ecological Planning, Unterdorfstraße 3, 63667 Nidda, Germany.

Received: 14 July 2019 Accepted: 11 November 2019

Published online: 28 November 2019

\section{References}

1. AG Boden - Arbeitsgruppe Boden (2005) Bodenkundliche Kartieranleitung, 5th edn. Bundesanstalt für Geowissenschaf-ten und Rohstoffe und den Geologischen Landesämtern der Bundesrepublik Deutschland (Hrsg.) Hannover

2. BfN (Bundesamt für Naturschutz; Hrsg.) (2010) Karte der Potenziellen Natürlichen Vegetation Deutschland, M 1:500.000. Bonn-Bad Godesberg, 24 S. Legende +7 Karten

3. CLC (2006) Karte der Bodenbedeckung, CORINE Land Cover 2006. https://www. eea.europa.eu/data-and-maps/data/corine-land-cover-2006-raster-2/clc-2006100m/g100 06.zip/at download/file/g100 06.zip. Accessed 10 July 2019

4. DDGI (2007) Qualitätsmodell für die Beschreibung von Geodaten (PAS 1071:2007-10). Beuth Verlag: Berlin, 14 S.+Anh

5. Friedrichs J (1990) Methoden empirischer Sozialforschung, 14th edn. Westdeutscher Verlag, Opladen, p 430

6. Hofmann G (2002) Entwicklung der Waldvegetation des nordostdeutschen Tieflandes unter den Bedingungen steigender Stickstoffeinträge in Verbindung mit Niederschlagsarmut. Mit Anlagen. In: Anders S et al (eds) Ökologie und Vegetation der Wälder Nordostdeutschlands. Dr. Kessel: Oberwinter, 24-41, 201-283. http://www.forstbuch.de

7. HVBG (2014) Digitales Basis-Landschaftsmodell (Basis-DLM) von Hessen. Hessische Verwaltung für Bodenmanagement und Geoinformation. http:// www.hvbg.hessen.de. Accessed 10 July 2019
8. ISO 2005 ISO (2005) Geographic information-quality principles (ISO 19113:2002); English version EN ISO 19113:2005

9. Jenssen M (2010) Modellierung und Kartierung räumlich differenzierter Wirkungen von Stickstoffeinträgen in Ökosysteme im Rahmen der UNECELuftreinhaltekonvention. Teilbericht IIII: Modellierung der Wirkung der Stickstoff-Deposition auf die biologische Vielfalt der Pflanzengesellschaften von Wäldern der gemäßigten Breiten UBA-Texte 09/2010. Dessau-Roßlau

10. Jenssen M, Hofmann G, Nickel S, Pesch R, Riediger J, Schröder W (2013) Bewertungskonzept für die Gefährdung der Ökosystemintegrität durch die Wirkungen des Klimawandels in Kombination mit Stoffeinträgen unter Beachtung von Ökosystemfunktionen und -dienstleistungen. Umweltforschungsplan des Bundesministeriums für Umwelt, Naturschutz und Reaktorsicherheit. Forschungsvorhaben 371083 214, UBA-FB 001834. UBATexte 87/2013. Dessau, Textband + 9 Anhänge, $381 \mathrm{~S}$

11. Jenssen M, Nickel S, Schröder W (2019) 61 Referenzzustände zur Beurteilung der ökologischen Integrität von Wald- und Forstökosystemen, Link zu Forschungsdaten (Version v1). ZENODO. https://doi.org/10.5281/ zenodo. 2582888

12. Jenssen M, Schröder W, Nickel S (2015) Typisierung von Wald- und Forstökosystemen als Grundlage zur Einstufung ihrer Integrität. Integrität von Wald- und Forstökosystemen unter dem Einfluss von Klimawandel und atmosphärischen Stickstoffeinträgen - Teil I. Naturschutz und Landschaftsplanung 47(12):391-399

13. Kullback S (1959) Information theory and statistics. Wiley, New York, p 395

14. Londo G (1974) The decimal scale for relevés of permanent quadrats. In: Knapp R (ed) Sampling methods in vegetation science. W. Junk Publishers, The Hague, pp 45-49

15. Maes J, Liuete C, Teller A, Erhard M, Paracchini ML, Barredo Jl, Grizzetti B, Cardoso A, Somma F, Petersen JE, Meiner A, Royo Gelabert E, Zal N, Kristensen P, Bastrup-Birk A, Biala K, Piroddi C, Egoh B, Lavalle C (2016) An indicator framework for assessing ecosystem services in support of the EU Biodiversity Strategy to 2020. Ecosyst Serv 17(14):23

16. Nickel S, Schröder W, Jenssen M (2015) Veränderungen deutscher Wälder durch Klimawandel und Stickstoffdeposition. Schweizerische Zeitschrift für Forstwesen 166(5):325-334

17. Nickel S, Schröder W, Jenssen M (2016) Prädiktive Kartierung und Analyse klimawandelbedingter Veränderungen von Wald- und Forstökosystemen. Integrität von Ökosystemen unter dem Einfluss von Klimawandel und atmosphärischen Stickstoffeinträgen - Teil III. Naturschutz und Landschaftsplanung 48(2):46-52

18. Riecken U, Finck P, Raths U, Schröder E, Ssymank A (2006) Rote Liste der gefährdeten Biotoptypen Deutschlands. Natursch Biol Vielf 34:1-318

19. Schröder W, Nickel S, Jenssen M, Riediger J (2015) Methodology to assess and map the potential development of forest ecosystems exposed to climate change and atmospheric nitrogen deposition: a pilot study in Germany. Sci Total Environ 521-522:108-122

20. Schröder W, Nickel S, Jenssen M, Hofmann G, Schlutow A, Nagel HD, Burkhard B, Dworczyk C, Elsasser P, Lorenz M, Meyerhoff J, Weller P, Altenbrunn K (2018) Anwendung des Bewertungskonzepts für die Ökosystemintegrität unter Berücksichtigung des Klimawandels in Kombination mit Stoffeinträgen. Abschlussbericht Forschungsvorhaben UFOPLAN 371383254 im Umweltforschungsplan des Bundesministeriums für Umwelt, Naturschutz, Bau und Reaktorsicherheit, Bd. 1: 1-493 + 7 Anhänge, Bd. 2: 1-343, Bd. 3: 1-303. Dessau

21. Schröder W, Riediger J, Nickel S, Jenssen M (2016) Projektion zukünftiger Ökosystemzustände unter dem Einfluss von Klimawandel und atmosphärischen Stickstoffeinträgen. Integrität von Wald- und Forstökosystemen unter dem Einfluss von Klimawandel und atmosphärischen Stickstoffeinträgen - Teil II. Naturschutz und Landschaftsplanung 48(1):22-28

22. Ssymank A, Hauke U, Rückriem C, Schröder E (1998) Das europäische Schutzgebietssystem NATURA 2000. BfN-Handbuch zur Umsetzung der Fauna-Flora-Habitat-Richtlinie (92/43/EWG) und der Vogelschutz-Richtlinie (79/409/EWG). Schriftenreihe Landschaftspflege und Naturschutz 53:1-560

\section{Publisher's Note}

Springer Nature remains neutral with regard to jurisdictional claims in published maps and institutional affiliations. 